\title{
Tubulin Gamma-1 Chain
}

National Cancer Institute

\section{Source}

National Cancer Institute. Tubulin Gamma-1 Chain. NCI Thesaurus. Code C38488.

Tubulin gamma-1 chain (451 aa, $\sim 51 \mathrm{kDa}$ ) is encoded by the human TUBG1 gene. This protein plays a role in the regulation of tubulin minus-end nucleation, centrosome duplication and spindle formation. 